\title{
金属元素の偏析した表面の作製と偏析による 仕事関数制御の可能性*
}

\author{
吉武 道子**.吉原 一紘**
}

（受理1993年11月30日，揭載決定1994年 1 月 8 日）

\begin{abstract}
Preparation of Metal Segregated Surface and the Potential of Work Function Control by Surface Segregation
\end{abstract}

Michiko YOSHITAKE and Kazuhiro YOSHIHARA

(National Research Institute for Metals, 1-2-1, Sengen, Tsukuba, Ibaraki)

(Received November 30, 1993, Accepted January 8, 1994)

\section{1. はじめに}

仕事関数は表面の性質を表す物理量の一つであるとと もに，低仕事関数の表面は電子銃のフィラメントなどに 利用されている．特に最近ではフィールドェミッタに対 する関心が高まっており, マイクロバキュームエレクト ロニクスや微小領域分析用の電子銃への応用が考えられ る.しかし，フィールドェミッタは表面の污染などによ り経時変化があり, 安定にエミッション電流を確保する ためにはエミッタ表面の組成を常に制御する必要があ る.

著者らは金属基板上に別の金属薄膜を蒸着したものを 真空中で加熱すると，基板金属が薄膜上に偏析し，偏析 表面では基板金属と薄膜金属の組成が一定になる現象を 見いだした1). 仕事関数は吸着により大きく変化する2) ので偏析によっても同様に変化すると予想される：そこ で薄膜での偏析現象を利用して仕事関数を制御すること を考劣, 予備的な実験を行った。

\section{2. 実験方法}

大きさ $10 \mathrm{~mm} \times 10 \mathrm{~mm} \times 1 \mathrm{~mm}$ の数種類の金属板を機 械研磨後アセトン洗浄したものを基板とし，別の金属の

\footnotetext{
* 平成 5 年 10 月 27 日 第 34 回真空に関する連合講演会で講演
}

** 茨城県つくば市千現 1-2-1（金属材料技術研究所）
薄膜を高周波マグネトロンスパッタ法により蒸着した。 基板及び蒸着に用いた金属の種類を Table 1 に示す. 蒸 着時のアルゴン圧は0.53 Pa, 基板は特に加熱や冷却は 行わなかった．薄膜を蒸着した試料をオージェ電子分光 (AES) 装置または X 線光電子分光 (XPS) 装置に導入 し, $10^{-7} \mathrm{~Pa}$ 台の真空中で加熱しながら表面組成を観察 した．基板元素が薄膜表面に現れた後試料を室温に戻し て,アルゴンイオンスパッタにより試料を研削しながら AES により組成を観測して深さ方向の組成分布を調べ， 薄膜表面に現れた基板元素が表面に偏析しているのか, それとも薄膜金属と合金，あるいは金属間化合物を生成 しているのかを判別した． Table 1 に示される薄膜一基 板の元素の組み合わせの内いくつかについては, 特定温 度における基板元素の表面組成の変化を観測した。

偏析による仕事関数の变化と密接な関係があると考え られる内殼電子の結合ェネルギー変化について, 次の 2 つの場合についてXPSにより調べた. (1) Cu 基板上に イオンビームスパッタ蒸着により Ti を蒸着しながら XPS スペクトルを測定し, Cu2 $\mathrm{p}_{3 / 2}$ の結合ェネルギーの 変化を $\mathrm{Ti}$ 蒸着量の関数として観測した. (2) $\mathrm{Ti}$ 膜 $/ \mathrm{Cu}$ 基 板を加熱することにより生成した Cu偏析表面での $\mathrm{Cu} 2 \mathrm{p}_{3 / 2}$ の結合エネルギーを測定し，この值を純銅及び 数種の $\mathrm{Ti}-\mathrm{Cu}$ 系金属間化合物の結合エネルギーと比較 した. 
Table 1 The segregation occurrence of substrate element in the several film/substrate combinations. $\bigcirc$ represents that substrate element segregates on the film surface. $\times$ represents it does not.

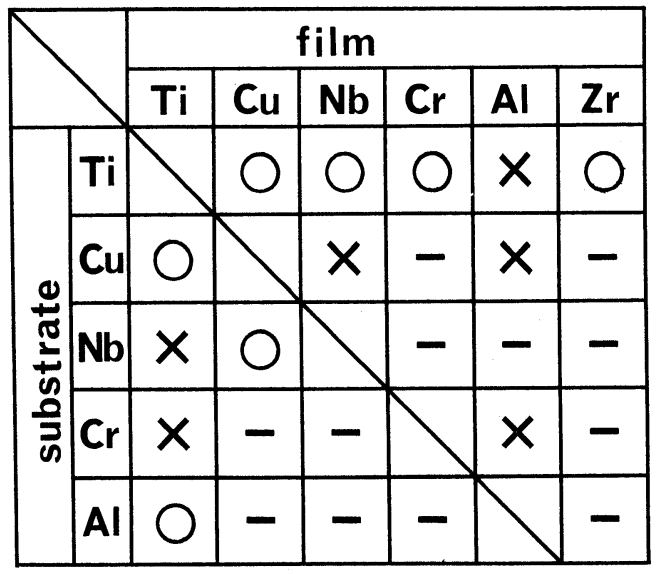

\section{3. 実験結果及び考察}

\section{1 偏析層の生成}

数種類の薄膜-基板の金属の組み合わせにおいて基板 元素の偏析がみられたかどらかを Table 1 に示した．表 中，○は基板元素が偏析したことを，×は偏析がみられ なかったことを，一は実験を行っていないことを示す.

基板元素の偏析における表面組成の変化の一例として, $\mathrm{Nb}$ 膜/ $\mathrm{Ti}$ 基板の場合 ${ }^{3)}$ を取り上げる.XPSにより測定 した表面 $\mathrm{Ti}$ 濃度を，(1)試料を真空中で $820 \mathrm{~K}$ に加熱, (2) Ti 濃度飽和後室温まで放冷したものをスパッタリン グ（スパッタ速度約 $21 \mathrm{~nm} / \mathrm{ks}$ ), (3)表面に Tiが無くな ったところで再加熱, という過程に拈いて観測すると, まず(1)の過程においては，一定時間後に基板元素である $\mathrm{Ti}$ が $\mathrm{Nb}$ 膜中を拡散して表面まで現れ，その濃度が増 加した後, 飽和濃度に達する. 次に(2)の過程において, 拡散の起こらない室温でスパッタリングすると表面から $20 \mathrm{~nm}$ 程度で完全に Ti が観測されなくなり，Tiは Nb 膜の表面付近にのみ存在する. さらに(3)で, 再加熱をし ようと $820 \mathrm{~K}$ まで昇温する途中の $740 \mathrm{~K} て ゙$ 既に Tiが観 測され始め, $820 \mathrm{~K}$ に到達して $1.8 \mathrm{ks}$ 程度で Ti は飽和 濃度に達した。 (1)と比べるとすぐに Ti が表面に現れて おり，スパッタにより Tiが観測されなくなっても， $\mathrm{Nb}$ 膜中には Ti が既に存在していることを示している. このように偏析層が消失した後再加熱により容易に偏析 層が再生されることは, 容易に表面組成を一定に制御で きるため, 電界電子放出源の材料として非常に好まし い.
Table 2 Bindingenergy of $\mathrm{Cu} 2 \mathrm{p}_{3 / 2}$.

\begin{tabular}{l|c}
\hline \hline & $\mathrm{Cu}_{2} \mathrm{p}_{3 / 2}(\mathrm{eV})$ \\
\hline segregated $\mathrm{Cu}$ & 932.91 \\
$\gamma-\mathrm{TiCu}$ & 932.90 \\
$\mathrm{Ti}_{3} \mathrm{Cu}_{4}$ & 932.80 \\
$\mathrm{TiCu}_{3}$ & 932.81 \\
$\mathrm{Cu}$ metal & 932.67 \\
\hline
\end{tabular}

\section{2 偏析による電子状態の変化}

$\mathrm{Cu}$ 原子が $5 \%$ 程度の濃度で $\mathrm{Ti}$ 膜上に偏析したとき の電子状態を，純金属と $\mathrm{TiCu}$ 金属間化合物の場合と， XPSにより測定した Cu2 $\mathrm{p}_{3 / 2}$ の結合エネルギーで比較 した結果を Table 2 に示す. 偏析した Cuの結合ェネル ギーは純銅のものより $0.24 \mathrm{eV}$ も高く金属間化合物 $\gamma$ $\mathrm{TiCu}$ の值に近い。偏析したときに $\mathrm{Cu}$ の濃度は約 $5 \%$ で飽和する4)ので，二次元の金属間化合物が生成されて いるといらことができる．結合ェネルギーが純銅よりも 高いことは，一般的には電子が $\mathrm{Cu}$ から $\mathrm{Ti}$ のほうに流 れていることを示しており，真空側にプラスの双極子が 生成して仕事関数を低下寸る方向に作用している(5)こと を示唆している.

Fig. 1 には， $\mathrm{Cu}$ 基板上に Tiを蒸着したときの $\mathrm{Cu} 2 \mathrm{p}_{3 / 2}$ の結合エネルギーの変化を $\mathrm{Ti}$ の蒸着量の関数 として示した。いちばん左の $\mathrm{Ti}$ 濃度 0 が純銅の結合ェ ネルギーである．Ti蒸着にしたがって Cuの結合エネ ルギーが高くなるのがわかる，ただし，観測では Ti と 接触している $\mathrm{Cu}$ のみを測定しているのではなく，より

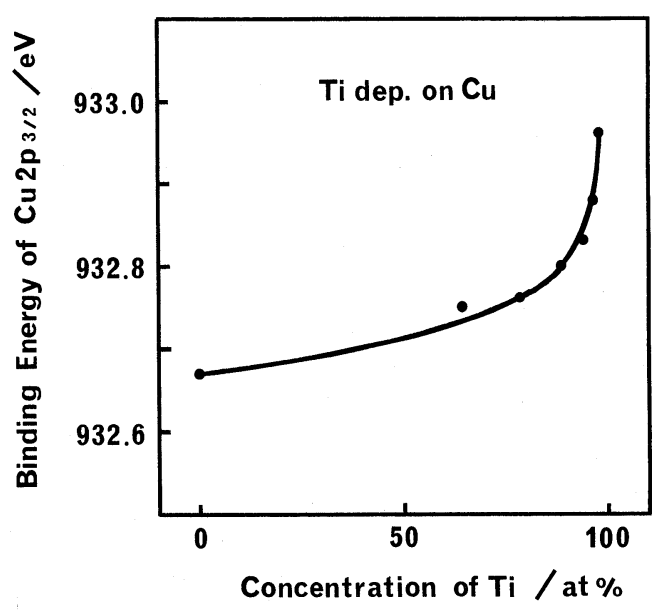

Fig. 1 The change of the binding energy of Cu2 $\mathrm{p}_{3 / 2}$ by $\mathrm{Ti}$ deposition on $\mathrm{Cu}$ substrate. 
深い $\mathrm{Cu}$ を含めた平均值となっており， $\mathrm{Ti}$ 濃度が $100 \%$ に近づくにつれて，Ti と接触している Cuが観測して いる大部分を占める．従って， Ti と接触している $\mathrm{Cu}$ の結合ェネルギーはTi 濃度が100\%に近いところの值 を取っていると考えられる、Ti濃度 $95 \%$ ，すなわち Cu $5 \%$ 程度の時の結合エネルギーは, Table 2 の偏析 $\mathrm{Cu}$ の値に近い。蒸着した場合でも電子は $\mathrm{Cu}$ 側から $\mathrm{Ti}$ へ流れていると推測される.

\section{$3.3 \mathrm{Ti}$ 上への $\mathrm{Cu}$ の吸着による仕事関数変化の予想}

以上の結果から， $\mathrm{Ti}$ 基板上に $\mathrm{Cu}$ を蒸着したときに $\mathrm{Cu}$ の結合エネルギーや仕事関数がどう変化するかを以 下のよらに予想してみた。まず Cuの結合エネルギーは $\mathrm{Ti}$ との接触で偏析 $\mathrm{Cu}$ の值に近いものとなり, $\mathrm{Cu}$ の蒸 着量が増加するにつれて基板の $\mathrm{Ti}$ の影響が減少して徐 々にバルクの值に近づき, 基板からのシグナルが観測さ れなくなる数十原子層程度でバルクの值になると予想さ れる。言い換えれば，Fig. 1 の横軸を逆に右から左へ $\mathrm{Cu}$ の蒸着量と読み変えたような結果が得られると予想 される. 仕事関数の変化は, 一般に, 結合エネルギーの 変化とパラレルではなく, 蒸着物質が一原子層に満たな いところで仕事関数の変化は最大となる6)。これは, 蒸 着物質と基板物質との間の電子移動により表面に生成し た電気双極子が, 蒸着量が増すと互いに相互作用し始 め, 電気双極子によるポテンシャルの低下が効果的に働 かなくなり, 最終的には蒸着物質の仕事関数に近づくた めと考えられている7)。ここでは, $\mathrm{Ti}$ 基板上に $\mathrm{Cu}$ が偏 析したときの $\mathrm{Cu}$ 量をもとに, どの程度の仕事関数の低 下か期待できるかを見積もってみる，電気双極子による 仕事関数の変化 $(\Delta \phi)$ は次のように書ける22.

$$
\Delta \phi=-4 \pi \mathrm{enp}
$$

ここで, $\mathrm{e}$ は電気素量, $\mathrm{n}$ は電気双極子の密度, $\mathrm{p}$ は電 気双極子の大きさを表し, GGS 静電単位系で表されて いる. $\mathrm{Ti}$ と $\mathrm{Cu}$ のオージェ電子の脱出深さ $0.108 \mathrm{~nm}$ 及 び $0.157 \mathrm{~nm}$ (文献 8 の方法により計算), Ti と $\mathrm{Cu}$ の相 対オージェピーク感度 0.45 及び 0.21 (純物質の強度から 計算), 電子検出角 $45^{\circ}$ で偏析時の $\mathrm{Cu}$ 濃度が約 $5 \%$ であ ること, を用いて Cuが Tiの表面第一層のみに存在し ているとしたときの被覆率を計算すると約 0.1 となる. $\mathrm{Ti}$ と $\mathrm{Cu}$ の原子半径 $0.147 \mathrm{~nm}$ 及び $0.128 \mathrm{~nm}^{9)}$ と被覆率 0.1 を用いて電気双極子の密度を計算すると, $\mathrm{n}=1.336 \times 10^{15}$ (個 $\left./ \mathrm{cm}^{2}\right)$ となる. $\mathrm{Cu}$ の結合エネルギ 一の変化から電気双極子の電荷の大きさを以下のように 見積もる. $\mathrm{Cu}^{0}$ と $\mathrm{Cu}^{+2}\left(\mathrm{CuF}_{2}\right)$ の結合エネルギーの違 いが $4.4 \mathrm{eV}^{10)}$ であることから電荷 $+2 \mathrm{e}$ で $4.4 \mathrm{eV}$ のシフ トと考え, $0.24 \mathrm{eV}$ のシフトは電荷 $0.11 \mathrm{e}$ に対応すると 考える. 正負の電荷の位置を原子の中心とすると, 上記
の原子半径から電荷の間の距離は0.232 nm となり, 電 気双極子の多きさは, $\mathrm{p}=1.226 \times 10^{-18}(\mathrm{esu} \cdot \mathrm{cm})$ とな る.これらの值を(1) 式に代入すると, $\Delta \phi=0.62 \mathrm{eV}$ と なり，偏析により表面双極子が生成され仕事関数を大き く低下することがでさることが予想される．

\section{4 表面清浄性の保持}

現在の電界放出電子源の問題点の一つは, 雾用気の残 留ガスがチップの金属表面に吸着して仕事関数を变化さ せるために, 電界放出電流の值に大きな経時変化がある といらことである.

著者らはさきに, $\mathrm{Nb}$ 膜/ $\mathrm{Ti}$ 基板を加熱して $\mathrm{Ti}$ が偏析 した表面に吸着した酸素原子が，約 $470 \mathrm{~K}$ 以上に加熱す ると内部に取り込まれることを示した ${ }^{11)}$ 。このゲッター 作用はゲッターを加熱すると真空容器内の分圧が低下す ることからわかるように, 吸着によるものでなくゲッタ 一内部に取り込むものである。Ti打よび $\mathrm{Nb}$ は, 仕事 関数が $4.33 \mathrm{eV}, 4.3 \mathrm{eV}$ とWの $4.55 \mathrm{eV}$ に比べても低 く12)電子源として利用でさる物質であり，この偏析した 材料を電界放出電子源に使えば, 吸着原子を内部に取り 込み表面は清浄に保たれる。

\section{4. まと め}

ある金属の表面に別の金属元素が偏析しているとき， その表面の電子状態はそれぞれの金属と大きく異なって おり，仕事関数を制御するのに利用できると考えられ る. 薄膜の偏析現象を利用すると $2 つ の$ 金属の表面組成 を一定に保つことができ，仕事関数の值が安定に保たれ ると期待される，また，蒸発による表面原子の損失に対 して, 基板から原子が供給されるので表面組成を回復す ることができる.さらに, 薄膜一基板の組み合わせによ っては，表面に存在する金属が雲囲気からの不純物を内 部に取り込む機能を持ち, 酸素などの吸着による性能の 劣化を防ぐと期待される．適切な薄膜一基板の組み合わ せを見い出すことにより, 薄膜での偏析現象を利用した 電子放出源材料は有望である.

\section{[文献]}

1）吉武道子, 吉原一紘 : 日本金属学会誌, 54 (1990) 778; 吉武道子, 吉原一紘：日本金属学会誌, 54 (1990) 1013; 吉武道子, 吉原一紘：日本金属学会誌, 55 （1991）727; 吉武道子, 吉原一紘：日本金属学会 誌，55（1991）773; 吉武道子, 吉原一紘：日本金属 学会誌, 56 (1992) 89. Michiko Yoshitake and Kazuhiro Yoshihara, Surface and Interface Analysis, 18 (1992) 509.

2) J. Kolaczkiewicz and E. Bauer, Surf. Sci. 160 (1985) 1.

3）吉武道子, 吉原一紘 : 日本金属学会誌, 投稿中. 
4）吉武道子, 吉原一紘：日本金属学会誌，54（1990） 778 .

5) J. Holzl: Surf. Sci., 247 (1991) 226.

6) D. R. Baer, C. W. Hubbard and R. L. Gordon: J. Vac. Sci. Technol., A10 2391 (1992).

7) G. E. Rhead: Surf. Sci., 203 L663 (1988).

8) S. Tanuma, D. R. Penn and C. J. Powell: Surf. Interf. Anal., 11 (1988) 577.
9）日本金属学会編集，「金属データブック」 p 8, 丸 善 (1984).

10) C. D. Wagner, W. M. Riggs, L. E. Davis, J. F. Moulder and G. E. Mullenberg: "Handbook of X-ray Photoelectron Spectroscopy", Perkin-Elmer Co., Physical Electronics Div., Eden Prairie, MN, USA.

11）吉武道子, 吉原一紘 : 真空, 33 (1990) 198.

12) H. B. Michaelson, J. Appl. Phys., 48 (1977) 4729. 